\title{
Advancing Animal Models of Human Type 1 Diabetes by Engraftment of Functional Human Tissues in Immunodeficient Mice
}

\author{
Michael A. Brehm ${ }^{1}$, Alvin C. Powers ${ }^{2}$, Leonard D. Shultz ${ }^{3}$, and \\ Dale L. Greiner ${ }^{4}$ \\ ${ }^{1}$ University of Massachusetts Medical School, Program in Molecular Medicine, Worcester, \\ Massachusetts 01605 \\ ${ }^{2}$ Vanderbilt University, Division of Diabetes, Endocrinology, and Metabolism, Vanderbilt University \\ Medical Center, Nashville, Tennessee 37232 \\ ${ }^{3}$ The Jackson Laboratory, Bar Harbor, Maine 04609 \\ ${ }^{4}$ University of Massachusetts Medical School, Program in Molecular Medicine, Worcester, \\ Massachusetts 01605 \\ Correspondence: Dale.greiner@umassmed.edu
}

\begin{abstract}
Despite decades of studying rodent models of type 1 diabetes (T1D), no therapy capable of preventing or curing T1D has successfully been translated from rodents to humans. This inability to translate otherwise promising therapies to clinical settings likely resides, to a major degree, from significant species-specific differences between rodent and human immune systems as well as species-related variances in islets in terms of their cellular composition, function, and gene expression. Indeed, taken collectively, these differences underscore the need to define interactions between the human immune system with human $\beta$ cells. Immunodeficient mice engrafted with human immune systems and human $\beta$ cells represent an interesting and promising opportunity to study these components in vivo. To meet this need, years of effort have been extended to develop mice depleted of undesirable components while at the same time, allowing the introduction of constituents necessary to recapitulate physiological settings as near as possible to human T1D. With this, these so-called "humanized mice" are currently being used as a preclinical bridge to facilitate identification and translation of novel discoveries to clinical settings.
\end{abstract}

$\mathrm{O}$ ur understanding of TID has been influenced greatly by studies performed using rodent models. The two rodent models studied most extensively are the nonobese diabetic (NOD) mouse and the biobreeding (BB) rat (Greiner et al. 2001). These two rodent models have helped define the autoimmune response that leads to the destruction of $\beta$ cells and to provide clues into the pathogenesis of T1D. These models have noted that T1D is characterized by a T-cell-mediated immune response against islet autoantigens, that it can be transferred with autoreactive lymphocytes (i.e., T cells), and that the autoimmunity persists long after the loss of

Editors: Jeffrey A. Bluestone, Mark A. Atkinson, and Peter R. Arvan

Additional Perspectives on Type 1 Diabetes available at www.perspectivesinmedicine.org

Copyright (C) 2012 Cold Spring Harbor Laboratory Press; all rights reserved; doi: 10.1101/cshperspect.a007757

Cite this article as Cold Spring Harb Perspect Med 2012;2:a007757 
M.A. Brehm et al.

$\beta$ cells, displaying recurrent autoimmunity when transplanted with syngeneic islets (Von and Nepom 2009). Similar patterns of pathogenesis have been observed in humans, particularly with respect to recurrent autoimmunity. A key observation made by Sutherland and colleagues (1984) showed that T1D individuals transplanted with kidneys and pancreas from identical twins retained the kidney graft, but rejected the islets in the pancreatic graft. Recurrent autoimmunity has also been observed following transplantation of allogeneic islets (Vendrame et al. 2010).

In addition to studies of T1D pathogenesis, rodent models have been used to investigate potential therapeutics for the treatment and cure of this disease (Staeva-Vieira et al. 2007). In the NOD mouse, 200 therapies have been shown to prevent diabetes (Atkinson and Leiter 1999). However, it must be noted that NOD mice are resistant to tolerance induction even to nonislet tissues and grafts (Pearson et al. 2003) and thus, their immune systems appear to differ in many respects from that of nonautoimmune mice. In the $\mathrm{BB}$ rat, far fewer therapies have been shown to prevent diabetes (Greiner et al. 2001). However, despite decades of studies with rat as well as mouse models of T1D, we have yet to successfully translate therapies that prevent, delay, or cure T1D in humans (Roep 2007; Staeva-Vieira et al. 2007; Couzin-Frankel 2011; Greenbaum and Atkinson 2011).

Underlying this failure is the increasing awareness that mouse and human immune systems, as well as islets, differ significantly in terms of their cell composition, function, and gene expression. These distinctive features of human immune systems and islets, combined with the need to translate emerging findings from rodent biology to human therapeutic efficacy, have formed roadblocks for translating discoveries in rodents to new approaches to prevent or delay T1D in humans.

\section{HUMAN ISLETS DIFFER SUBSTANTIALLY FROM RODENT ISLETS}

Mouse and human pancreatic islets as the target of autoimmune attack differ in many ways, including cellular architecture and composition, proliferative capacity, susceptibility to injury, ability to form islet amyloid, and expression of heat-shock proteins, islet-enriched transcription factors, antioxidant enzymes, and the principal glucose transporter (i.e., GLUT1 vs. GLUT2) (Eizirik et al. 1994; Welsh et al. 1995; Brissova et al. 2005; Butler et al. 2007). In contrast to the more familiar rodent islet cellular architecture (characterized by non- $\beta$ endocrine cells surrounding the inner $\beta$-cell mass), the endocrine cells in human islets are more intermingled (Brissova et al. 2005; Cabrera et al. 2006; Bosco et al. 2010). Furthermore, in contrast to rodent $\beta$ cells that replicate or regenerate in response to a number of stimuli such as insulin resistance, $\beta$-cell ablation, and partial pancreatectomy, the human $\beta$-cell proliferative capacity appears to be very modest and often nonexistent (Butler et al. 2007).

\section{HUMAN IMMUNE SYSTEMS DIFFER SIGNIFICANTLY FROM RODENT IMMUNE SYSTEMS}

Of particular interest in the study of autoimmunity are the differences between human and mouse immune systems (Mestas and Hughes 2001). The first and foremost difference involves the major histocompatibility complex (MHC), a primary genetic factor for determining diabetes susceptibility. In the NOD mouse, the MHC class $\mathrm{I}$ is $\mathrm{K}^{\mathrm{d}} \mathrm{D}^{\mathrm{b}}$, with a unique I-A $\mathrm{A}^{\mathrm{g} 7}$ class II molecule. The initial CD4 T-cell autoimmune response in NOD mice appears to be directed against insulin (Atkinson et al. 1990; Zhang et al. 1991 ) and specifically, against an epitope of insulin (B9-23) presented by the I-A ${ }^{\mathrm{g} 7}$ class II molecule (Abiru et al. 2001). On the basis of these observations, the NIH Diabetes Prevention Trial-1 was initiated, but this study suggested a beneficial effect (i.e., delay in developing disease) in only a small subgroup of individuals at high risk for T1D and treated with oral insulin (whole molecule); no beneficial influence was seen with prophylactic daily subcutaneous administration of this antigen (Skyler et al. 2005). In humans, the B9-23 epitope does not appear to be the dominant insulin epitope 
Animal Models of Human Type 1 Diabetes

(Skowera et al. 2008; Dromey et al. 2011). Moreover, using NOD mice deficient in mouse MHC class I and expressing human HLA-A2, it has been observed that a primary initiating autoantigenic epitope appears to be IGRP $265-273$ (Niens et al. 2011). Another key difference between the study of T1D pathogenesis in rodents and humans is their environment. Mice and rats in most animal facilities are housed under specific pathogen-free (SPF) conditions in which they are not exposed to pathogenic infectious agents. In contrast, humans are not only exposed to infectious agents, they are also immunized to these agents, leading to the generation of effector/memory immune responses that generate immune systems that may cross-react with islet autoantigens (Sarugeri et al. 2001; Tong et al. 2002; Chou et al. 2004).

Mice and humans also differ in their balance of leukocyte subsets, defensins, inducible nitric oxide synthase (NOS), $\gamma / \delta$ T cells, and natural killer $(\mathrm{NK})$ inhibitory receptor families, cells, and molecules that are important players in immune and autoimmune responses (Mestas and Hughes 2001). The T-cell signaling pathways and costimulatory molecule expression of humans and rodents also shows many differences, as does their cytokine and chemokine receptor expression. Of particular interest are differences in the innate immune responses that are known to play a critical role in the generation of an adaptive immune response. For example, following IV injection of lipopolysaccharide, humans are as much as 100,000-fold more susceptible to endotoxin shock than mice (Munford 2010). In addition, the Tolllike receptor (TLR) repertoires that control innate immune responses also differ substantially. TLR11 is expressed in mice but not in humans; indeed, this gene has stop codons that prevent its expression. Conversely, TLR10 is expressed in humans, but in mice this TLR is a pseudogene. With this setting, the community of translational investigators is in great need of improved small animal models that would more effectively identify human-specific agents that will prove successful in human T1D (Greenbaum and Atkinson 2011).

\section{SCID Mice-A Paradigm Shift in T1D Research}

As described above, progress in understanding the pathogenesis, as well as analyses of the efficacy of therapeutics for T1D, has been impeded by considerable differences of rodent models and human disease. This is compounded by our inability to analyze in vivo the interaction of diabetogenic human immune cells with human islets without placing individuals at risk (Atkinson et al. 2000). One potential approach to overcome these limitations is to study this interaction in vivo by engraftment of human immune cells and islets into immunodeficient mice.

\section{Engraftment of Human Immune Systems in Genetically Modified SCID Mice}

Progress in development of effective small animal models to facilitate in vivo studies of human adaptive immune responses followed the discovery of the severe combined immunodeficiency (Prkdc scid , abbreviated as scid) mutation in a colony of CB17 mice (Bosma et al. 1983). However, the utility of the CB17-scid model, particularly for studies of human immunity and autoimmune disease such as T1D, is limited by low levels of human hematolymphoid cell engraftment owing to host adaptive and innate immune factors, including elevated NK cell activity (Bosma et al. 1988; Shultz et al. 1995; Peled et al. 1999). Improved engraftment has been achieved in NOD-scid mice (Greiner et al. 1998), but these mice still express detectable NK activity and innate immunity that impedes human hematolymphoid cell engraftment. To improve human hematolymphoid cell engraftment, differentiation, and immune function in immunodeficient mice, two general approaches have been pursued: (1) additional genetic modification of the host and (2) development of new protocols for engraftment.

\section{GENETIC MODIFICATION: INTERLEUKIN-2 RECEPTOR COMMON $\gamma$ CHAIN NULL IMMUNODEFICIENT MURINE HOSTS}

An alternative method for decreasing innate immunity in scid, Rag1 $1^{\text {null }}$, or Rag $2^{\text {null }}$ immunodeficient mice involves genetic intercrossing 
M.A. Brehm et al.

with mice carrying a targeted mutation at the IL-2ry common chain (Shultz et al. 2007). Deficiency of IL-2 receptor $\gamma$ chain causes X-linked SCID in humans (Uribe and Weinberg 1998). This molecule is indispensable for IL2, IL4, IL7, IL9, IL15, and IL21 high-affinity binding and signaling (Sugamura et al. 1996).

IL-2ry common chain deficiency completely blocks NK cell development and causes additional defects in innate immunity (Shultz et al. 2007). Research groups have independently produced targeted IL-2 receptor $\gamma$ chain mutations (Cao et al. 1995; DiSanto et al. 1995; Ohbo et al. 1996). Ito et al. (2002) backcrossed a truncated IL2r $\gamma$ mutation onto the NOD/Shi-scid strain. Adult NOD/Shi-scid IL $2 r \gamma^{\text {null }}$ mice injected IV with human $\mathrm{CD}^{+} 4^{+}$umbilical cord blood (UCB) cells results in the generation of a functional human immune system (Ito et al. 2002; Yahata et al. 2002). Traggiai et al. (2004) engrafted BALB/c-Rag2 $2^{\text {null }}$ IL2 $r \gamma^{\text {null }}$ mice generated using an IL2r $\gamma^{\text {null }}$ truncated knockout originally made by Ito et al. (2002), and injection of newborn mice with human hematopoietic stem cells (HSC) generated a functional adaptive immune system (Traggiai et al. 2004). Our laboratories have generated NOD/Lt-scid IL2r $\gamma^{\text {null }}$ (NSG) mice using a complete null mutation of the IL2r $\gamma$ gene and have documented that both adult and newborn mice engrafted with human HSC generate functional human immune systems (Ishikawa et al. 2005; Shultz et al. 2005, 2007; Brehm et al. 2010b).

\section{The NSG Mouse}

Focusing our efforts on NSG mice (Shultz et al. 2007), we have shown that these mice are superior to all other stocks of IL2r $\gamma^{\text {null }}$ mice in their ability to support engraftment with a functional human immune system (Shultz et al. 2007; Pearson et al. 2008a; Brehm et al. 2010b;). Because of the ability of NSG mice to engraft at high levels with mature human lymphocytes and HSC, NSG mice are ideal hosts for investigating the in vivo function of human immune and autoimmune systems. These preclinical models can also be used to identify mechanisms by which therapeutic interventions for T1D mediate their effects.

A number of human immune engraftment models have been developed that can be used to study human immune cell function, including the Hu-PBL-SCID, Hu-SRC-SCID, and the BLT (i.e., fetal hematopoietic stem cell, liver, thymus) models (Table 1). The Hu-PBL-SCID model is based on injection of human peripheral blood leukocytes (PBL) or splenocytes into NSG mice and is used for the analyses of mature immune and autoreactive T cells and the effector arm of the immune system. This model has been used to examine both alloimmunity and autoimmunity as well as viral immunity (Shultz et al. 2007). The Hu-SRC-SCID model is based on the engraftment of HSC. This model develops functional innate and adaptive human immune systems, including all of the cells of

Table 1. Models of human immune systems in immunodeficient mice

\begin{tabular}{|c|c|c|}
\hline Model & Characteristics & Uses \\
\hline Hu-PBL-SCID & $\begin{array}{l}\text { Immunodeficient mice engrafted with } \\
\text { human PBMCs }\end{array}$ & $\begin{array}{l}\text { Study of human-specific infectious agents, } \\
\text { alloimmunity and autoimmunity in } \\
\text { vivo }\end{array}$ \\
\hline Hu-SRC-SCID & $\begin{array}{l}\text { Immunodeficient mice engrafted with } \\
\text { human HSCs }\end{array}$ & $\begin{array}{l}\text { Study of human HSC and development } \\
\text { of a functional human immune } \\
\text { system }\end{array}$ \\
\hline SCID-hu (BLT) & $\begin{array}{l}\text { Immunodeficient mice engrafted under } \\
\text { the renal capsule with human fetal } \\
\text { liver/thymus and injected IV with } \\
\text { fetal liver HSC }\end{array}$ & $\begin{array}{l}\text { Study of human HSC, T-cell development } \\
\text { and intrathymic selection and } \\
\text { development of a functional human } \\
\text { immune system }\end{array}$ \\
\hline
\end{tabular}

Abbreviations: PBL, peripheral blood leukocytes; PBMCs, peripheral blood mononuclear cell cultures; SRC, scidrepopulating cell; BLT, bone marrow/liver/thymus; HSCs, hematopoietic stem cells. 
hematopoietic lineage, and has been used to study many aspects of human immunobiology (Shultz et al. 2007; Manz and Di Santo 2009). In the BLT model, mice are engrafted under the renal capsule with fragments of human fetal liver and thymus, and injected intravenously with human HSC derived from the liver of the same donor tissue (McCune et al. 1988; Namikawa et al. 1988; Melkus et al. 2006; Sun et al. 2007; Denton et al. 2008; Wege et al. 2008; Denton and Garcia 2009). These mice also develop functional innate and adaptive human immune systems, but in this model human $\mathrm{T}$ cells are educated on autologous human thymic epithelium, leading to robust HLA-restricted human immunity.

\section{Models to Study Human Islet Function and Allo- and Autoimmunity}

\section{NSG Normoglycemic Mice}

One simple model to study the function of human islets in the absence of potential effects of glucose toxicity encountered following transplantation of human islets into hyperglycemic mice involves the transplantation of human islets into normoglycemic NSG mice. We have observed that we can evaluate human islet function by their ability to secrete human insulin and C-peptide following glucose administration (unpublished observations).

The NSG model system will allow the analyses of development and function of reprogrammed, ES (embryonic stem) and induced pluripotent stem (iPS) -derived $\beta$ cells in a normoglycemic environment. It should also be noted that euglycemia in a mouse is $\sim 120$ $160 \mathrm{mg} / \mathrm{dL}$, whereas the "set point" in humans is $\sim 80-100 \mathrm{mg} / \mathrm{dL}$, essentially exposing the human $\beta$ cells to chronic low hyperglycemic stimulation even in a "normoglycemic" mouse host. Despite this, there are numerous advantages for the use of this model system. These include (1) normoglycemic NSG mice are readily available in essentially unlimited numbers, (2) transplanted cells are not exposed to high levels of glucose, avoiding the potential confounding effects of glucose toxicity, (3) fewer cells are required for functional analyses than are required for regulation of hyperglycemia in diabetic recipients, and (4) this model has been shown to successfully support the engraftment of mouse and human islets. Finally, (5) we have published a "gold standard" protocol for how to establish human immune systems in these immunodeficient mice (Pearson et al. 2008a), permitting investigation of the function of human islets or $\beta$ cells in the presence of alloreactive and, in the future, autoreactive immune systems. The disadvantages of this model include the inability to determine if the engrafted islets or $\beta$ cells can function properly with respect to their ability to regulate hyperglycemia in vivo.

\section{Chemically Induced Hyperglycemic NSG Mice}

NSG mice have been induced to become hyperglycemic by the injection of streptozotocin (STZ) (King et al. 2008; Pearson et al. 2008b). Transplantation of human or mouse islets, or dissociated mouse islet insulin-positive cells can restore normoglycemia. These mice can also be engrafted with functional human immune systems following injection of human peripheral blood mononuclear cells (PBMC, the Hu-PBL-SCID model) (King et al. 2009; Pino et al. 2009) or human HSC (the Hu-SRC-SCID model) (Shultz et al. 2005; Giassi et al. 2008; Jaiswal et al. 2009; Brehm et al. 2010a). Data validating the ability of the NSG mouse model to serve as recipients of human islets and human immune systems has been published (Shultz et al. 2007). Advantages for the use of this model system include (1) readily available NSG mice in essentially unlimited numbers, (2) the ability to induce hyperglycemia at will, (3) human and mouse islets and dissociated mouse islet cells (single-cell suspensions of insulin-positive cells) can restore normoglycemia, and (4) the NSG mice can be engrafted with a functional human immune system. The disadvantages of this model are the inconsistent induction of hyperglycemia in STZ-treated mice, the potential for "reversion" of the hyperglycemia by recovery of the endogenous mouse islets, and toxicity of STZ. 
M.A. Brehm et al.

\section{Monogenetic Models of Hyperglycemia}

The use of chemical toxins for the induction of hyperglycemia has a number of drawbacks as described above. To address this, a number of monogenic mouse models of hyperglycemia have been described. These include, among others, the Ins2 ${ }^{\text {Akita }}$ (Akita), the Eif2ak3 (PERK) knockout, the Fxn (frataxin) and Tfam conditional knockouts, and the Ncb5or (NCB5OR knockout) strains (Table 2). Our laboratory has focused on the use of the Ins $2^{\text {Akita }}$ model of spontaneous diabetes as a foundation strain for the generation of a monogenic model of genetically induced spontaneous hyperglycemia.

\section{NOD-Rag1 ${ }^{\text {null }}$ Prf1 $^{\text {null }}$ Ins $2^{\text {Akita }}$ Mouse Model}

The dominant mutation in the murine insulin 2 gene, termed Ins $2^{\text {Akita }}$, results in spontaneous nonimmune mediated hyperglycemia (Yoshioka et al. 1997; Mathews et al. 2002). This spontaneously arising mutation replaces a cysteine at position 96 with tyrosine, and disrupts a disulfide linkage required for proper folding of

Table 2. Monogenic mouse models of insulin-dependent diabetes

\begin{tabular}{|c|c|c|c|c|}
\hline Mouse model & $\begin{array}{l}\text { Gene } \\
\text { symbol }\end{array}$ & Phenotype & Human disease & References \\
\hline $\begin{array}{l}\text { AKITA } \\
\text { Spontaneous } \\
\text { mutation in insulin-2 } \\
\text { gene }\end{array}$ & Ins $2^{\text {Akita }}$ & $\begin{array}{l}\text { Spontaneous insulin- } \\
\text { dependent diabetes }\end{array}$ & $\begin{array}{l}\text { Permanent } \\
\text { neonatal/ } \\
\text { infancy-onset } \\
\text { diabetes mellitus } \\
\text { (PNDM) }\end{array}$ & $\begin{array}{l}\text { Yoshioka et al. 1997; } \\
\text { Wang et al. 1999; } \\
\text { Colombo et al. } \\
2008\end{array}$ \\
\hline $\begin{array}{l}\text { PERK } \\
\text { Phosphorylation of } \\
\text { eukaryotic translation } \\
\text { initiation factor } 2 \alpha \\
\text { kinase } 3 \text { knockout }\end{array}$ & Eif2ak3 & $\begin{array}{l}\text { PERK knockout mice } \\
\text { show progressive loss } \\
\text { of } \alpha \beta \text { cells as well as } \\
\text { loss in pancreatic } \\
\text { acinar cell viability }\end{array}$ & $\begin{array}{l}\text { Walcott-Rallison } \\
\text { syndrome }\end{array}$ & $\begin{array}{l}\text { Shi et al. 1998; } \\
\text { Harding et al. } \\
\text { 1999; Zhang et al. } \\
\text { 2002; Cavener } \\
\text { et al. 2010; Julier } \\
\text { and Nicolino } 2010\end{array}$ \\
\hline $\begin{array}{l}\text { FRATAXIN } \\
\text { Nuclear-encoded } \\
\text { protein localized at } \\
\text { the mitochondrial } \\
\text { matrix conditional } \\
\text { knockout }\end{array}$ & Fxn & $\begin{array}{l}\text { Conditional disruption } \\
\text { in } \beta \text { cells results in } \\
\text { diabetes owing to } \\
\text { loss of } \beta \text {-cell mass }\end{array}$ & Freidrich's ataxia & $\begin{array}{l}\text { Cossee et al. 2000; } \\
\text { Ristow et al. 2000, } \\
\text { 2003; Pandolfo } \\
\text { 2003; Gucev et al. } \\
2009\end{array}$ \\
\hline $\begin{array}{l}\text { TFAM } \\
\text { Mitochondrial } \\
\text { transcription factor A } \\
\text { Nuclear-encoded } \\
\text { mitochondrial protein } \\
\text { Conditional knockout } \\
\text { NCB50r }\end{array}$ & Tfam & $\begin{array}{l}\text { Conditional disruption } \\
\text { in } \beta \text { cells results in } \\
\text { impaired insulin } \\
\text { secretion and } \\
\text { hyperglycemia by } 5 \\
\text { wk of age }\end{array}$ & $\begin{array}{l}\text { Mitochondrial } \\
\text { diabetes }\end{array}$ & $\begin{array}{l}\text { Larsson et al. 1998; } \\
\text { Silva et al. 2000; } \\
\text { Maassen et al. } \\
\text { 2002; Falkenberg } \\
\text { et al. } 2007\end{array}$ \\
\hline $\begin{array}{l}\text { NCB5OR } \\
\text { Cytochrome B5 } \\
\text { reductase } 4 \\
\text { Soluble flavoheme } \\
\text { NAD }(\mathrm{P}) \mathrm{H} \text { reductase } \\
\text { localized in the ER } \\
\text { protects } \beta \text { cells from } \\
\text { oxidative stress }\end{array}$ & $\begin{array}{l}\text { Cyb5r4 } \\
\text { Old } \\
\text { symbol } \\
(\text { Ncb5or })\end{array}$ & $\begin{array}{l}\text { Cyb5r4 knockout mice } \\
\text { develop severe } \\
\text { hyperglycemia by } 7 \\
\text { wk of age } \\
\text { accompanied by } \\
\text { hepatic lipid } \\
\text { metabolic } \\
\text { abnormalities }\end{array}$ & $\begin{array}{l}\text { No reported } \\
\text { association with } \\
\text { diabetes in } \\
\text { humans }\end{array}$ & $\begin{array}{l}\text { Andersen et al. 2004; } \\
\text { Xie et al. 2004; Xu } \\
\text { et al. } 2011\end{array}$ \\
\hline
\end{tabular}

Abbreviation: ER, endoplasmic reticulum. 
insulin. Improper folding of the nascent insulin 2 molecule, induction of the unfolded protein response, and finally apoptosis of $\beta$ cells leads to diabetes and permanent hyperglycemia (Ron 2002; Izumi et al. 2003). We generated a strain of immunodeficient spontaneously hyperglycemic mice, the NOD-Rag1 $1^{\text {null }}$ Prf1 ${ }^{\text {null }}$ Ins $2^{\text {Akita }}$ strain. The NOD-Rag $1^{\text {null }} \operatorname{Prf1} 1^{\text {null }}$ Ins $2^{\text {Akita }}$ strain was based on the previously described NODRag1 $1^{\text {null }} \operatorname{Prf1}^{\text {null }}$ strain that was shown to accept human islet transplants and allowed for allograft rejection following engraftment with human PBMC (Banuelos et al. 2004). NOD-Rag1 null Prf1 ${ }^{\text {null }}$ Ins $2^{\text {Akita }}$ mice develop spontaneous hyperglycemia, similar to Ins $2^{\text {Akita }}$-harboring strains of immunocompetent mice (Pearson et al. 2008b). There was no mononuclear cell infiltration into the islets that had spontaneously lost $\beta$ cells, and human islets transplanted into diabetic NOD-Rag1 ${ }^{\text {null }} \operatorname{Prf1} 1^{\text {null }}$ Ins $2^{\text {Akita }}$ mice resulted in a return to euglycemia.

Immunodeficient NOD mice harboring the Ins $2^{\text {Akita }}$ mutation are an appealing host for human islet transplants and for human $\beta$ stem and progenitor cells when concerns about drug-induced hyperglycemia are encountered. Advantages of this model are (1) spontaneous development of hyperglycemia in the absence of administration of toxic drugs, (2) consistent and severe hyperglycemia, (3) no "reversion" of the hyperglycemia by recovery of the endogenous mouse islets, and (4) no need for administration of exogenous insulin to prevent the development of metabolic decompensation and death. Disadvantages of this model include the inability of NOD-Rag1 $1^{\text {null }} \operatorname{Prf1} 1^{\text {null }}$ Ins $2^{+/ A k i t a}$ mice to support consistent levels of human PBMC or HSC engraftment and the inability of HSC engraftment to generate a fully functional human immune system, including T cells (Shultz et al. 2003; Banuelos et al. 2004; Minamiguchi et al. 2005).

NOD-Rag1 $1^{\text {null } I L-2 r} \gamma^{\text {null }}$ Ins $2^{\text {Akita }}$

Mouse Model

The NOD-Rag1 ${ }^{\text {null }}$ IL-2r $\gamma^{\text {null Ins2 }} 2^{\text {Akita }}$ (NRGAkita) mouse model of spontaneous hyperglycemia has recently been described (Brehm et al. 2010a), and these mice become hyperglycemic with the same kinetics as do NOD-Rag1 ${ }^{\text {null }}$ Prf1 ${ }^{\text {null }}$ Ins $2^{\text {Akita }}$ mice (Pearson et al. 2008b). Furthermore, human islets can also restore normoglycemia in diabetic NRG-Akita mice. A major advantage of these mice is that they can be engrafted with a fully functional human immune system (Brehm et al. 2010b) that can reject transplanted allogeneic human islets (Brehm et al. 2010a). This model has all the advantages of the NOD-Rag1 $1^{\text {null }} \operatorname{Prf1} 1^{\text {null }}$ Ins $2^{\text {Akita }}$ model plus the ability to support engraftment with functional human immune systems so that alloimmunity and autoimmunity can be studied in these mice.

\section{New Models of Hyperglycemia under Development}

\section{NOD-Scid IL-2r $\gamma^{\text {null }} \operatorname{Tg}($ Ins-rtTA) $\operatorname{Tg}(T E T-D T A)$ Strain of Mice}

This mouse model developed by Drs. Nir, Dor, and Melton expresses diphtheria toxin A (DTA) in $\beta$ cells following addition of doxycycline to the drinking water (Nir et al. 2007). Expression of a single DTA molecule is toxic to mouse $\beta$ cells, and the mice have been shown to remain hyperglycemic throughout the period of doxycycline administration. Following removal of doxycycline, the $\beta$ cells proliferate and restore normoglycemia (Nir et al. 2007). The generation of these mice by speed congenic backcrossing of the Ins-rtTA and TETDTA transgenes to the NSG strain is currently under way.

\section{NOD-Scid IL-2r $\gamma^{\text {null }} \operatorname{Tg}(R I P-H u D T R)$ Strain of Mice}

The $T g(R I P-H u D T R)$ model system developed by Dr. Herrera (Thorel et al. 2010) is currently being backcrossed onto the NSG strain. Both $\mathrm{X}$-linked and autosomal versions of the model are under development. In the X-linked model system, administration of diphtheria toxin to hemizygous female mice will lead to a loss of $50 \%$ of $\beta$ cells, whereas administration of diphtheria toxin to the autosomal model will result in up to $99 \%$ elimination of the $\beta$-cell mass 
M.A. Brehm et al.

(Thorel et al. 2010). These models will permit timing of the induction of hyperglycemia to be precisely controlled.

Use of Immunodeficient Mice for the In Vivo Study of Human $\beta$-Cell Proliferation

It is well known that mouse $\beta$ cells can be induced to proliferation in the presence of hyperglycemia (Schuit and Drucker 2008), but it is unknown whether human $\beta$ cells will also experience proliferation under similar stimulation. Based on the ability of immunodeficient mice to accept human islet grafts, two groups have recently used these model systems to study the ability of hyperglycemia to induce human $\beta$-cell proliferation in vivo. In one study, human islets were transplanted into STZ-diabetic NODscid mice, and the mice were injected with BrdU (Levitt et al. 2011). In the second study, human islets were transplanted into diabetic NRG-Akita mice (DiIorio et al. 2011). In both studies, human $\beta$ cells were observed to increase their proliferation rates in a hyperglycemic environment, but the rate of proliferation was much lower than that observed in mouse islets subjected to similar hyperglycemic conditions (Schuit and Drucker 2008). These model systems can now be used for the study of human $\beta$-cell responses to experimental drugs and to human immune and autoimmune systems.

\section{Models for the Study of Human T1D \\ Hu-PBL-SCID Model}

One approach for the study of human T1D in immunodeficient mice is the use of the $\mathrm{Hu}$ PBL-SCID model. This model has historically been used to study multiple types of autoimmunity (Tighe et al. 1990; Martin et al. 1992; Davis et al. 2002), including T1D (Petersen et al. 1993). Although the autoantibodies to islet components were detected following PBL transfer from individuals with T1D, no infiltration or $\beta$-cell destruction was observed (Petersen et al. 1993). More recently, the development of human T-cell clones with specificities for islet autoantigens has permitted the study of adop- tive transfer of diabetes into NOD-scid mice. In these studies, infiltration, but not islet cell destruction was detected (van Halteren et al. 2005). The availability of newer strains of immunodeficient mice based on the IL2r $\gamma^{\text {null }} \mathrm{mu}$ tation and transgenic expression of human HLA molecules has provided models that now appear to permit the direct study of human autoreactive $\mathrm{T}$ cells in vivo. A recent manuscript has used NSG-HLA-A2 mice as recipients of HLA-A2 PBMC from T1D and non-T1D donors, and reported that in the Hu-PBL-SCID model system, peripheral blood lymphocytes from T1D patients preferentially infiltrated the islets of NSG-HLA-A2 recipients (Whitfield-Larry et al. 2011). Using splenocytes from T1D donors obtained through the nPOD program supported by JDRF, we have obtained similar results in that splenocytes from HLA-A2 T1D donors preferentially induce insulitis in NSG-HLA-A2 recipients (unpublished observations).

\section{Hu-SRC-SCID Model}

Although the Hu-PBL-SCID model enables in vivo analyses of functional mature human $\mathrm{T}$ cells, other cell lineages fail to engraft efficiently following injection of PBMC (Shultz et al. 2007). In rodent models of T1D, other immune cell lineages, including macrophages, NK cells, NKT cells, dendritic cells, and B cells have been implicated in the pathogenesis of T1D (Von and Nepom 2009). These additional human cell lineages can be generated in immunodeficient mice by engraftment of HSC. However, to engraft HSC from a donor with a genetic susceptibility for T1D requires the recovery of HSC from T1D donors via bone marrow biopsies or mobilization of HSC into the peripheral blood following G-CSF treatment. Alternatively, in the virus research community, TCRs from virus-specific human T-cell clones have been generated and lentivirus constructs containing these TCRs have been used to transduce human HSC that are subsequently transplanted into immunodeficient mice. For example, HIV-specific TCR constructs were used to transduce HSC ("retrogenic" approach), and these engrafted HSCs generated mature HLA-restricted 
cytotoxic CD8 T cells expressing this "transgenic" TCR (Kitchen et al. 2009). A large number of human islet autoantigenic epitopes have been identified (Di Lorenzo et al. 2007). In addition, autoreactive T-cell clones are now becoming available. These tools now permit the TCR "retrogenic" approach used successfully for the study of HIV to be applied to the study of T1D.

\section{iPS Cells for the Study of Human T1D}

Recent breakthroughs in the ability to "reprogram" cells into pluripotent stem cells that can be used via directed differentiation to generate all cell lineages have been reported (Cohen and Melton 2011). Various groups are now generating iPS cells derived from T1D donors, and are pursing the directed differentiation of these cells into $\beta$ cells, HSC, and thymic epithelium. If successful, this approach would permit T1D genetically susceptible HSC to be educated on autologous thymic epithelium with autologous $\beta$ cells as targets of the autoimmune response. In rodent models, it is well known that HSC can transfer diabetes to adoptive recipients (Greiner et al. 2001; Von and Nepom 2009), and isolated case reports have suggested this is also true for humans (Lampeter et al. 1998, 1993; Mellouli et al. 2009). This system would allow the analysis of the relative importance of different diabetic genotypes, risk loci, and environmental stimuli on the etiology of T1D, and may thus identify novel points for therapeutic intervention.

\section{CONCLUDING REMARKS}

Despite many decades of studying rodent models of T1D, we have yet to translate therapies that prevent or cure T1D in rodents to the successful prevention or cure of T1D in humans. This is in part owing to the fact that rodent and human immune systems, as well as their islets, differ significantly in terms of cell composition, function, and gene expression. These differences form the basis for our need to understand interactions of human autoimmune systems with human $\beta$ cells to allow successful translation of emerging findings from rodent biology to humans. The use of novel immunodeficient mouse models engrafted with functional human immune systems and islets is now providing the tools to investigate specific mechanisms by which alloimmune and diabetogenic human immune cells attack human $\beta$ cells and how $\beta$ cells respond to immune attack. Findings from this approach can guide the development of novel strategies to prevent and cure T1D. This information, because is it based on human cells, tissues, and immune systems, has the potential to translate directly into information that will identify targets for therapeutic intervention, guide clinical trials, and ultimately transform our understanding of human T1D.

\section{ACKNOWLEDGMENTS}

This work is supported by National Institutes of Health research grants AI46629 (DLG, LDS, MAB), AI083911 (MAB), HL077642 (LDS), CA34196 (LDS), AI073871 (DLG, LDS), DK 32520 (DLG, LDS), P30 AI042845 (MAB), DK 66636 (ACP), DK69603 (ACP), DK68854 (ACP), DK72473 (DLG, LDS, ACP), DK89572 (DLG, LDS, ACP), DK20593, and grants from the Juvenile Diabetes Foundation, International (DLG, LDS, MAB, ACP), the Helmsley Foundation (DLG, LDS, MAB), and the VA Research Service (ACP). Human islets were provided by JDRF-supported islet isolation centers and the Islet Cell Resource Centers and the Integrated Islet Distribution Network (http://iidp.coh. org/). Human spleen samples were provided by the JDRF Network for Pancreatic Organ Donors with Diabetes (nPOD). The contents of this publication are solely the responsibility of the authors and do not necessarily represent the official views of the National Institutes of Health.

\section{REFERENCES}

\footnotetext{
Abiru N, Maniatis AK, Yu L, Miao D, Moriyama H, Wegmann D, Eisenbarth GS. 2001. Peptide and major histocompatibility complex-specific breaking of humora tolerance to native insulin with the B9-23 peptide in diabetes-prone and normal mice. Diabetes 50: 1274-1281.

Andersen G, Wegner L, Rose CS, Xie J, Zhu H, Larade K, Johansen A, Ek J, Lauenborg J, Drivsholm T, et al. 2004. Variation in NCB5OR: Studies of relationships to type 2 diabetes, maturity-onset diabetes of the young, and gestational diabetes mellitus. Diabetes 53: 2992-2997.
} 
M.A. Brehm et al.

Atkinson M, Leiter EH. 1999. The NOD mouse model of insulin dependent diabetes: As good as it gets? Nat Med 5: 601-604.

Atkinson MA, Maclaren NK, Luchetta R. 1990. Insulitis and diabetes in NOD mice reduced by prophylactic insulin therapy. Diabetes 39: 933-937.

Atkinson MA, Honeyman MC, Peakman M, Roep BO. 2000. T-cell markers in type 1 diabetes: Progress, prospects and realistic expectations. Diabetologia 43: 819-820.

Banuelos SJ, Shultz LD, Greiner DL, Burzenski LM, Gott B, Lyons BL, Rossini AA, Appel MC. 2004. Rejection of human islets and human HLA-A2.1 transgenic mouse islets by alloreactive human lymphocytes in immunodeficient NOD-scid and NOD-Rag1 ${ }^{\text {null }}$ Prf1 ${ }^{\text {null }}$ mice. Clin Immunol 112: 273-283.

Bosco D, Armanet M, Morel P, Niclauss N, Sgroi A, Muller YD, Giovannoni L, Parnaud G, Berney T. 2010. Unique arrangement of $\alpha$ - and $\beta$-cells in human islets of Langerhans. Diabetes 59: 1202-1210.

Bosma GC, Custer RP, Bosma MJ. 1983. A severe combined immunodeficiency mutation in the mouse. Nature 301: 527-530.

Bosma GC, Fried M, Custer RP, Carroll A, Gibson DM, Bosma MJ. 1988. Evidence of functional lymphocytes in some (leaky) scid mice. J Exp Med 167: 1016-1033.

Brehm MA, Bortell R, Dilorio P, Leif J, Laning J, Cuthbert A, Yang C, Herlihy M, Burzenski L, Gott B, et al. 2010a. Human immune system development and rejection of human islet allografts in spontaneously diabetic NODRag1 ${ }^{\text {null }}$ IL2rg ${ }^{\text {null }}$ Ins $2^{\text {Akita }}$ mice. Diabetes 59: 2265-2270.

Brehm MA, Cuthbert A, Yang C, Miller DM, Dilorio P, Laning J, Burzenski L, Gott B, Foreman O, Kavirayani A, et al. 2010b. Parameters for establishing humanized mouse models to study human immunity: Analysis of human hematopoietic stem cell engraftment in three immunodeficient strains of mice bearing the IL2r $\gamma^{\text {null }}$ mutation. Clin Immunol 135: 84-98.

Brissova M, Fowler MJ, Nicholson WE, Chu A, Hirshberg B, Harlan DM, Powers AC. 2005. Assessment of human pancreatic islet architecture and composition by laser scanning confocal microscopy. J Histochem Cytochem 53: 1087-1097.

Butler PC, Meier JJ, Butler AE, Bhushan A. 2007. The replication of $\beta$ cells in normal physiology, in disease and for therapy. Nat Clin Pract Endocrinol Metab 3: 758-768.

Cabrera O, Berman DM, Kenyon NS, Ricordi C, Berggren PO, Caicedo A. 2006. The unique cytoarchitecture of human pancreatic islets has implications for islet cell function. Proc Natl Acad Sci 103: 2334-2339.

Cao X, Shores EW, Hu-Li J, Anver MR, Kelsall BL, Russell SM, Drago J, Noguchi M, Grinberg A, Bloom ET, et al. 1995. Defective lymphoid development in mice lacking expression of the common cytokine receptor $\gamma$ chain. Immunity 2: 223-238.

Cavener DR, Gupta S, McGrath BC. 2010. PERK in $\beta$ cell biology and insulin biogenesis. Trends Endocrinol Metab 21: 714-721.

Chou CC, Lin KH, Ke GM, Tung YC, Chao MC, Cheng JY, Chen BH. 2004. Comparison of nucleotide sequence of p2C region in diabetogenic and non-diabetogenic Coxsacie virus B5 isolates. Kaohsiung J Med Sci 20: 525-532.
Cohen DE, Melton D. 2011. Turning straw into gold: Directing cell fate for regenerative medicine. Nat Rev Genet 12: 243-252.

Colombo C, Porzio O, Liu M, Massa O, Vasta M, Salardi S, Beccaria L, Monciotti C, Toni S, Pedersen O, et al. 2008. Seven mutations in the human insulin gene linked to permanent neonatal/infancy-onset diabetes mellitus. $J$ Clin Invest 118: 2148-2156.

Cossee M, Puccio H, Gansmuller A, Koutnikova H, Dierich A, Lemeur M, Fischbeck K, Dolle P, Koenig M. 2000. Inactivation of the Friedreich ataxia mouse gene leads to early embryonic lethality without iron accumulation. Hum Mol Genet 9: 1219-1226.

Couzin-Frankel J. 2011. Clinical studies. Trying to reset the clock on type 1 diabetes. Science 333: 819-821.

Davis LS, Sackler M, Brezinschek RI, Lightfoot E, Bailey JL, Oppenheimer-Marks N, Lipsky PE. 2002. Inflammation, immune reactivity, and angiogenesis in a severe combined immunodeficiency model of rheumatoid arthritis. Am J Pathol 160: 357-367.

Denton PW, Garcia JV. 2009. Novel humanized murine models for HIV research. Curr HIV/AIDS Rep 6: 13-19.

Denton PW, Estes JD, Sun Z, Othieno FA, Wei BL, Wege AK, Powell DA, Payne D, Haase AT, Garcia JV. 2008. Antiretroviral pre-exposure prophylaxis prevents vaginal transmission of HIV-1 in humanized BLT mice. PLoS Med 5: e16.

Di Lorenzo TP, Peakman M, Roep BO. 2007. Translational mini-review series on type 1 diabetes: Systematic analysis of $\mathrm{T}$ cell epitopes in autoimmune diabetes. Clin Exp Immunol 148: 1-16.

DiIorio P, Jurczyk A, Yang C, Racki W, Brehm MA, Atkinson MA, Powers AC, Shultz LD, Greiner DL, Bortell R. 2011. Hyperglycemia-induced proliferation of adult human $\beta$ cells engrafted into spontaneously diabetic immunodeficient NOD-Rrag1 $1^{\text {nul }}$ IL2rg ${ }^{\text {null }}$ Ins2 ${ }^{\text {Akita }}$ mice. Pancreas 40: 1147-1149.

DiSanto JP, Muller W, Guy-Grand D, Fischer A, Rajewsky K. 1995. Lymphoid development in mice with a targeted deletion of the interleukin 2 receptor $\gamma$ chain. Proc Natl Acad Sci 92: 377-381.

Dromey JA, Lee BH, Yu H, Young HE, Thearle DJ, Jensen KP, Mannering SI, Harrison LC. 2011. Generation and expansion of regulatory human $\mathrm{CD} 4^{+} \mathrm{T}$-cell clones specific for pancreatic islet autoantigens. J Autoimmun 36: 4755 .

Eizirik DL, Pipeleers DG, Ling Z, Welsh N, Hellerstrom C, Andersson A. 1994. Major species differences between humans and rodents in the susceptibility to pancreatic B-cell injury. Proc Natl Acad Sci 91: 9253-9256.

Falkenberg M, Larsson NG, Gustafsson CM. 2007. DNA replication and transcription in mammalian mitochondria. Annu Rev Biochem 76: 679-699.

Giassi LJ, Pearson T, Shultz LD, Laning J, Biber K, Kraus M, Woda BA, Schmidt MR, Woodland RT, Rossini AA, et al. 2008. Expanded CD $34^{+}$human umbilical cord blood cells generate multiple lymphohematopoietic lineages in NOD-scid IL2r $\gamma^{\text {null }}$ mice. Exp Biol Med (Maywood) 233: 997-1012.

Greenbaum C, Atkinson MA. 2011. Persistence is the twin sister of excellence: An important lesson for attempts to 
prevent and reverse type 1 diabetes. Diabetes 60: 693694.

Greiner DL, Hesselton RA, Shultz LD. 1998. SCID mouse models of human stem cell engraftment. Stem Cells 16: 166-177.

Greiner DL, Rossini AA, Mordes JP. 2001. Translating data from animal models into methods for preventing human autoimmune diabetes mellitus: Caveat emptor and primum non nocere. Clin Immunol 100: 134-143.

Gucev Z, Tasic V, Jancevska A, Popjordanova N, Koceva S, Kuturec M, Sabolic V. 2009. Friedreich ataxia (FA) associated with diabetes mellitus type 1 and hyperthrophic cardiomyopathy. Bosn J Basic Med Sci 9: 107-110.

Harding HP, Zhang Y, Ron D. 1999. Protein translation and folding are coupled by an endoplasmic-reticulum-resident kinase. Nature 397: 271-274.

Ishikawa F, Yasukawa M, Lyons B, Yoshida S, Miyamoto T, Yoshimoto G, Watanabe T, Akashi K, Shultz LD, Harada M. 2005. Development of functional human blood and immune systems in NOD/SCID/IL2 receptor $\gamma$ chain $^{\text {null }}$ mice. Blood 106: 1565-1573.

Ito M, Hiramatsu H, Kobayashi K, Suzue K, Kawahata M, Hioki K, Ueyama Y, Koyanagi Y, Sugamura K, Tsuji K, et al. 2002. NOD/SCID $\gamma_{c}^{\text {null }}$ mouse: An excellent recipient mouse model for engraftment of human cells. Blood 100: $3175-3182$.

Izumi T, Yokota-Hashimoto H, Zhao S, Wang J, Halban PA, Takeuchi T. 2003. Dominant negative pathogenesis by mutant proinsulin in the Akita diabetic mouse. Diabetes 52: $409-416$.

Jaiswal S, Pearson T, Friberg H, Shultz LD, Greiner DL, Rothman AL, Mathew A. 2009. Dengue virus infection and virus-specific HLA-A2 restricted immune responses in humanized NOD-scid IL2r $\gamma^{\text {null }}$ mice. PLoS ONE 4: e7251.

Julier C, Nicolino M. 2010. Wolcott-Rallison syndrome. Orphanet J Rare Dis 5: 29.

King M, Pearson T, Shultz LD, Leif J, Bottino R, Trucco M, Atkinson MA, Wasserfall C, Herold KC, Woodland RT, et al. 2008. A new Hu-PBL model for the study of human islet alloreactivity based on NOD-scid mice bearing a targeted mutation in the IL-2 receptor $\gamma$ chain gene. Clin Immunol 126: 303-314.

King MA, Covassin L, Brehm MA, Racki W, Pearson T, Leif J, Laning J, Fodor W, Foreman O, Burzenski L, et al. 2009. Hu-PBL-NOD-scid IL2rgull mouse model of xenogeneic graft-versus-host-like disease and the role of host MHC. Clin Exp Immunol 157: 104-118.

Kitchen SG, Bennett M, Galic Z, Kim J, Xu Q, Young A, Lieberman A, Joseph A, Goldstein H, Ng H, et al. 2009. Engineering antigen-specific $\mathrm{T}$ cells from genetically modified human hematopoietic stem cells in immunodeficient mice. PLoS ONE 4: e8208.

Lampeter EF, Homberg M, Quabeck K, Schaefer UW, Wernet P, Bertrams J, Grosse-Wilde H, Gries FA, Kolb H. 1993. Transfer of insulin-dependent diabetes between HLA-identical siblings by bone marrow transplantation. Lancet 341: 1243-1244.

Lampeter EF, McCann SR, Kolb H. 1998. Transfer of diabetes type 1 by bone-marrow transplantation. Lancet 351: $568-569$.
Larsson NG, Wang J, Wilhelmsson H, Oldfors A, Rustin P, Lewandoski M, Barsh GS, Clayton DA. 1998. Mitochondrial transcription factor $\mathrm{A}$ is necessary for mtDNA maintenance and embryogenesis in mice. Nat Genet 18: 231-236.

Levitt HE, Cyphert TJ, Pascoe JL, Hollern DA, Abraham N, Lundell RJ, Rosa T, Romano LC, Zou B, O’Donnell CP, et al. 2011. Glucose stimulates human $\beta$ cell replication in vivo in islets transplanted into NOD-severe combined immunodeficiency (SCID) mice. Diabetologia 54: 572582.

Maassen JA, Janssen GM, Lemkes HH. 2002. Mitochondrial diabetes mellitus. J Endocrinol Invest 25: 477-484.

Manz MG, Di Santo JP. 2009. Renaissance for mouse models of human hematopoiesis and immunobiology. Nat Immunol 10: 1039-1042.

Martin A, Kimura H, Thung S, Fong P, Shultz LD, Davies TF. 1992. Characteristics of long-term human thyroid peroxidase autoantibody secretion in scid mice transplanted with lymphocytes from patients with autoimmune thyroiditis. Int Arch Allergy Immunol 98: 317-323.

Mathews CE, Langley SH, Leiter EH. 2002. New mouse model to study islet transplantation in insulin-dependent diabetes mellitus. Transplantation 73: 1333-1336.

McCune JM, Namikawa R, Kaneshima H, Shultz LD, Lieberman M, Weissman IL. 1988. The SCID-hu mouse: Murine model for the analysis of human hematolymphoid differentiation and function. Science 241: 1632-1639.

Melkus MW, Estes JD, Padgett-Thomas A, Gatlin J, Denton PW, Othieno FA, Wege AK, Haase AT, Garcia JV. 2006. Humanized mice mount specific adaptive and innate immune responses to EBV and TSST-1. Nat Med 12: 1316-1322.

Mellouli F, Ksouri H, Torjmen L, Abdelkefi A, Ladeb S, Ben OT, Ben HA, Bejaoui M. 2009. Transmission of type 1 diabetes by bone marrow transplantation: A case report. Pediatr Transplant 13: 119-122.

Mestas J, Hughes CC. 2001. Endothelial cell costimulation of $\mathrm{T}$ cell activation through CD58-CD2 interactions involves lipid raft aggregation. J Immunol 167: 4378-4385.

Minamiguchi H, Wingard JR, Laver JH, Mainali ES, Shultz LD, Ogawa M. 2005. An assay for human hematopoietic stem cells based on transplantation into nonobese diabetic recombination activating gene-null perforin-null mice. Biol Blood Marrow Transplant 11: 487-494.

Munford RS. 2010. Murine responses to endotoxin: Another dirty little secret? J Infect Dis 201: 175-177.

Namikawa R, Kaneshima H, Lieberman M, Weissman IL, McCune JM. 1988. Infection of the SCID-hu mouse by HIV-1. Science 242: 1684-1686.

Niens M, Grier AE, Marron M, Kay TW, Greiner DL, Serreze DV. 2011. Prevention of "humanized" diabetogenic CD8 T-cell responses in HLA-transgenic NOD mice by a multipeptide coupled-cell approach. Diabetes 60: 12291236.

Nir T, Melton DA, Dor Y. 2007. Recovery from diabetes in mice by $\beta$ cell regeneration. J Clin Invest 117: 2553-2561.

Ohbo K, Suda T, Hashiyama M, Mantani A, Ikebe M, Miyakawa K, Moriyama M, Nakamura M, Katsuki M, Takahashi K, et al. 1996. Modulation of hematopoiesis in mice 
M.A. Brehm et al.

with a truncated mutant of the interleukin-2 receptor $\gamma$ chain. Blood 87: 956-967.

Pandolfo M. 2003. Friedreich ataxia. Semin Pediatr Neurol 10: $163-172$.

Pearson T, Markees TG, Wicker LS, Serreze DV, Peterson LB, Mordes JP, Rossini AA, Greiner DL. 2003. NOD congenic mice genetically protected from autoimmune diabetes remain resistant to transplantation tolerance induction. Diabetes 52: 321-326.

Pearson T, Greiner DL, Shultz LD. 2008a. Creation of "humanized" mice to study human immunity. Curr Protoc Immunol Chap. 15: Unit 15.12.

Pearson T, Shultz LD, Lief J, Burzenski L, Gott B, Chase T, Foreman O, Rossini AA, Bottino R, Trucco M, et al. 2008b. A new immunodeficient hyperglycaemic mouse model based on the Ins $2^{\text {Akita }}$ mutation for analyses of human islet and $\beta$ stem and progenitor cell function. Diabetologia 51: 1449-1456.

Peled A, Petit I, Kollet O, Magid M, Ponomaryov T, Byk T, Nagler A, Ben-Hur H, Many A, Shultz LD, et al. 1999. Dependence of human stem cell engraftment and repopulation of NOD/SCID mice on CXCR4. Science 283: 845-848.

Petersen JS, Marshall MO, Baekkeskov S, Hejnaes KR, Hoier-Madsen M, Dyrberg T. 1993. Transfer of type 1 (insulin-dependent) diabetes mellitus associated autoimmunity to mice with severe combined immunodeficiency (SCID). Diabetologia 36: 510-515.

Pino SC, Brehm MA, Covassin L, King M, Chase T, Wagner J, Burzenski L, Foreman O, Greiner DL, Shultz LD. 2009. Development of novel major histocompatibility complex class I and class II-deficient NOD-SCID IL2R $\gamma$ chain knockout mice for modeling human xenogeneic graftversus-host disease. In Mouse models for drug discovery: Methods and protocols. Humana Press, New York.

Ristow M, Pfister MF, Yee AJ, Schubert M, Michael L, Zhang CY, Ueki K, Michael MD, Lowell BB, Kahn CR. 2000. Frataxin activates mitochondrial energy conversion and oxidative phosphorylation. Proc Natl Acad Sci 97: $12239-12243$.

Ristow M, Mulder H, Pomplun D, Schulz TJ, MullerSchmehl K, Krause A, Fex M, Puccio H, Muller J, Isken $F$, et al. 2003. Frataxin deficiency in pancreatic islets causes diabetes due to loss of $\beta$ cell mass. J Clin Invest 112: 527-534.

Roep BO. 2007. Are insights gained from NOD mice sufficient to guide clinical translation? Another inconvenient truth. Ann NY Acad Sci 1103: 1-10.

Ron D. 2002. Proteotoxicity in the endoplasmic reticulum: Lessons from the Akita diabetic mouse. J Clin Invest 109: 443-445.

Sarugeri E, Dozio N, Meschi F, Pastore MR, Bonifacio E. 2001. T cell responses to type 1 diabetes related peptides sharing homologous regions. J Mol Med 79: 213-220.

Schuit FC, Drucker DJ. 2008. $\beta$-cell replication by loosening the brakes of glucagon-like peptide-1 receptor signaling. Diabetes 57: 529-531.

Shi Y, Vattem KM, Sood R, An J, Liang J, Stramm L, Wek RC. 1998. Identification and characterization of pancreatic eukaryotic initiation factor $2 \alpha$-subunit kinase, PEK, involved in translational control. Mol Cell Biol 18: 7499-7509.
Shultz LD, Schweitzer PA, Christianson SW, Gott B, Schweitzer IB, McKenna S, Mobraaten L, Rajan TV, Greiner EL, Leiter EH. 1995. Multiple defects in innate and adaptive immunologic function in NOD/LtSz-scid mice. J Immunol 154: 180-191.

Shultz LD, Banuelos S, Lyons B, Samuels R, Burzenski L, Gott B, Lang P, Leif J, Appel M, Rossini A, et al. 2003. NOD/LtSz-Rag1 ${ }^{\text {null }}$ Prf1 ${ }^{\text {null }}$ mice: A new model system with increased levels of human peripheral leukocyte and hematmopoietic stem cell engraftment. Transplantation 76: $1036-1042$.

Shultz LD, Lyons BL, Burzenski LM, Gott B, Chen X, Chaleff S, Gillies SD, King M, Mangada J, Greiner DL, et al. 2005. Human lymphoid and myeloid cell development in NOD/LtSz-scid IL2rg ${ }^{\text {null }}$ mice engrafted with mobilized human hematopoietic stem cell. J Immunol 174: 64776489.

Shultz LD, Ishikawa F, Greiner DL. 2007. Humanized mice in translational biomedical research. Nat Rev Immunol 7: $118-130$.

Silva JP, Kohler M, Graff C, Oldfors A, Magnuson MA, Berggren PO, Larsson NG. 2000. Impaired insulin secretion and $\beta$-cell loss in tissue-specific knockout mice with mitochondrial diabetes. Nat Genet 26: 336-340.

Skowera A, Ellis RJ, Varela-Calvino R, Arif S, Huang GC, Van Krinks C, Zaremba A, Rackham C, Allen JS, Tree TI, et al. 2008. CTLs are targeted to kill $\beta$ cells in patients with type 1 diabetes through recognition of a glucose-regulated preproinsulin epitope. J Clin Invest 118: 3390-3402.

Skyler JS, Krischer JP, Wolfsdorf J, Cowie C, Palmer JP, Greenbaum C, Cuthbertson D, Rafkin-Mervis LE, Chase HP, Leschek E. 2005. Effects of oral insulin in relatives of patients with type 1 diabetes: The diabetes prevention trial-Type 1. Diabetes Care 28: 1068-1076.

Staeva-Vieira T, Peakman M, von Herrath M. 2007. Translational mini-review series on type 1 diabetes: Immunebased therapeutic approaches for type 1 diabetes. Clin Exp Immunol 148: 17-31.

Sugamura K, Asao H, Kondo M, Tanaka N, Ishii N, Ohbo K, Nakamura M, Takeshita T. 1996. The interleukin-2 receptor $\gamma$ chain: Its role in the multiple cytokine receptor complexes and T cell development in XSCID. Annu Rev Immunol 14: 179-205.

Sun Z, Denton PW, Estes JD, Othieno FA, Wei BL, Wege AK, Melkus MW, Padgett-Thomas A, Zupancic M, Haase AT, et al. 2007. Intrarectal transmission, systemic infection, and $\mathrm{CD} 4^{+} \mathrm{T}$ cell depletion in humanized mice infected with HIV-1. J Exp Med 204: 705-714.

Sutherland DE, Sibley R, Xu XZ, Michael A, Srikanta AM, Taub F, Najarian J, Goetz FC. 1984. Twin-to-twin pancreas transplantation: Reversal and reenactment of the pathogenesis of type I diabetes. Trans Assoc Am Physicians 97: $80-87$.

Thorel F, Nepote V, Avril I, Kohno K, Desgraz R, Chera S, Herrera PL. 2010. Conversion of adult pancreatic $\alpha$-cells to $\beta$-cells after extreme $\beta$-cell loss. Nature 464: 11491154.

Tighe H, Silverman GJ, Kozin F, Tucker R, Gulizia R, Peebles C, Lotz M, Rhodes G, Machold K, Mosier DE, et al. 1990. Autoantibody production by severe combined immunodeficient mice reconstituted with synovial cells from 
rheumatoid arthritis patients. Eur J Immunol 20: 1843 1848.

Tong JC, Myers MA, Mackay IR, Zimmet PZ, Rowley MJ. 2002. The PEVKEK region of the pyridoxal phosphate binding domain of GAD65 expresses a dominant B cell epitope for type 1 diabetes sera. Ann NY Acad Sci 958: $182-189$.

Traggiai E, Chicha L, Mazzucchelli L, Bronz L, Piffaretti JC Lanzavecchia A, Manz MG. 2004. Development of a human adaptive immune system in cord blood cell-transplanted mice. Science 304: 104-107.

Uribe L, Weinberg KI. 1998. X-linked SCID and other defects of cytokine pathways. Semin Hematol 35: 299-309.

van Halteren AG, Kardol MJ, Mulder A, Roep BO. 2005. Homing of human autoreactive $T$ cells into pancreatic tissue of NOD-scid mice. Diabetologia 48: 75-82.

Vendrame F, Pileggi A, Laughlin E, Allende G, Martin-Pagola A, Molano RD, Diamantopoulos S, Standifer N, Geubtner KA, Falk BA, et al. 2010. Recurrence of type 1 diabetes after simultaneous pancreas-kidney transplantation, despite immunosuppression, is associated with autoantibodies and pathogenic autoreactive CD4 T-cells. Diabetes 59: 947-957.

Von HM, Nepom GT. 2009. Animal models of human type 1 diabetes. Nat Immunol 10: 129-132.

Wang J, Takeuchi T, Tanaka S, Kubo SK, Kayo T, Lu D, Takata K, Koizumi A, Izumi T. 1999. A mutation in the insulin 2 gene induces diabetes with severe pancreatic $\beta$-cell dysfunction in the Mody mouse. J Clin Invest 103: 27-37.

Wege AK, Melkus MW, Denton PW, Estes JD, Garcia JV. 2008. Functional and phenotypic characterization of the humanized BLT mouse model. Curr Top Microbiol Immunol 324: 149-165.

Welsh N, Margulis B, Borg LA, Wiklund HJ, Saldeen J, Flodstrom M, Mello MA, Andersson A, Pipeleers DG, Hellerstrom C, et al. 1995. Differences in the expression of heatshock proteins and antioxidant enzymes between human
Animal Models of Human Type 1 Diabetes

and rodent pancreatic islets: Implications for the pathogenesis of insulin-dependent diabetes mellitus. Mol Med 1: 806-820.

Whitfield-Larry F, Young EF, Talmage G, Fudge E, Azam A, Patel S, Largay J, Byrd W, Buse J, Calikoglu AS, et al. 2011. HLA-A2-matched peripheral blood mononuclear cells from type 1 diabetic patients, but not nondiabetic donors, transfer insulitis to NOD-scid $/ \gamma c^{\text {null }} /$ HLA-A2 transgenic mice concurrent with the expansion of isletspecific CD8 ${ }^{+} \mathrm{T}$ cells. Diabetes 60: 1726-1733.

Xie J, Zhu H, Larade K, Ladoux A, Seguritan A, Chu M, Ito S, Bronson RT, Leiter EH, Zhang CY, et al. 2004. Absence of a reductase, NCB5OR, causes insulin-deficient diabetes. Proc Natl Acad Sci 101: 10750-10755.

Xu M, Wang W, Frontera JR, Neely, Lu J, Aires D, Hsu FF, Turk J, Swerdlow RH, Carlson SE, Zhu H. 2011. Ncb5or deficiency increases fatty acid catabolism and oxidative stress. J Biol Chem 286: 11141-11154.

Yahata T, Ando K, Nakamura Y, Ueyama Y, Shimamura K, Tamaoki N, Kato S, Hotta T. 2002. Functional human T lymphocyte development from cord blood $\mathrm{CD} 34^{+}$cells in nonobese diabetic/Shi-scid, IL-2 receptor $\gamma$ null mice. J Immunol 169: 204-209.

Yoshioka M, Kayo T, Ikeda T, Koizumi A. 1997. A novel locus, Mody4, distal to D7Mit189 on chromosome 7 determines early-onset NIDDM in nonobese C57BL/6 (Akita) mutant mice. Diabetes 46: 887-894.

Zhang ZJ, Davidson L, Eisenbarth G, Weiner HL. 1991. Suppression of diabetes in nonobese diabetic mice by oral administration of porcine insulin. Proc Natl Acad Sci 88: 10252-10256.

Zhang P, McGrath B, Li S, Frank A, Zambito F, Reinert J, Gannon M, Ma K, McNaughton K, Cavener DR. 2002. The PERK eukaryotic initiation factor $2 \alpha$ kinase is required for the development of the skeletal system, postnatal growth, and the function and viability of the pancreas. Mol Cell Biol 22: 3864-3874. 


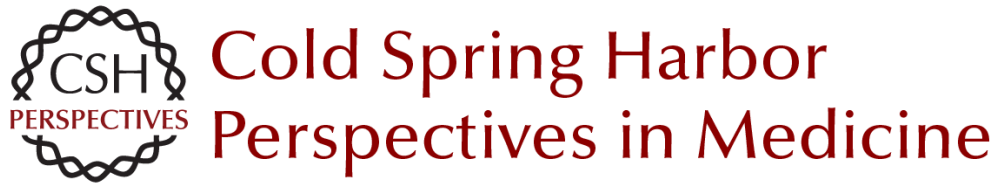

\title{
Advancing Animal Models of Human Type 1 Diabetes by Engraftment of Functional Human Tissues in Immunodeficient Mice
}

\author{
Michael A. Brehm, Alvin C. Powers, Leonard D. Shultz and Dale L. Greiner
}

Cold Spring Harb Perspect Med 2012; doi: 10.1101/cshperspect.a007757

\section{Subject Collection Type I Diabetes}

The Pathogenesis and Natural History of Type 1

Diabetes

Mark A. Atkinson

Do MHCII-Presented Neoantigens Drive Type 1

Diabetes and Other Autoimmune Diseases? Philippa Marrack and John W. Kappler

Clinical Immunologic Interventions for the

Treatment of Type 1 Diabetes

Lucienne Chatenoud, Katharina Warncke and

Anette-G. Ziegler

Update on Islet Transplantation

Michael McCall and A.M. James Shapiro

Immunologic and Metabolic Biomarkers of $\beta$-Cell

Destruction in the Diagnosis of Type 1 Diabetes Jasmin Lebastchi and Kevan C. Herold

Advancing Animal Models of Human Type 1

Diabetes by Engraftment of Functional Human

Tissues in Immunodeficient Mice

Michael A. Brehm, Alvin C. Powers, Leonard D.

Shultz, et al.

Breakdown in Peripheral Tolerance in Type 1

Diabetes in Mice and Humans

Lukas T. Jeker, Hélène Bour-Jordan and Jeffrey A. Bluestone

Antigen-Specific Therapeutic Approaches in Type 1 Diabetes

Xavier Clemente-Casares, Sue Tsai, Carol Huang, et al.
Humoral Autoimmunity in Type 1 Diabetes:

Prediction, Significance, and Detection of Distinct

Disease Subtypes

Massimo Pietropaolo, Roberto Towns and George

S. Eisenbarth

Endoplasmic Reticulum Stress, Pancreatic $\beta$-Cell

Degeneration, and Diabetes

Feroz R. Papa

Islet Autoantigens: Structure, Function,

Localization, and Regulation

Peter Arvan, Massimo Pietropaolo, David Ostrov, et al.

Environmental Triggers of Type 1 Diabetes Mikael Knip and Olli Simell

Generating $\beta$ Cells from Stem Cells--The Story So

Far Matthias Hebrok

Antigen Targets of Type 1 Diabetes Autoimmunity Bart O. Roep and Mark Peakman

Connecting Type 1 and Type 2 Diabetes through Innate Immunity

Justin I. Odegaard and Ajay Chawla

The Hygiene Hypothesis: An Explanation for the Increased Frequency of Insulin-Dependent

Diabetes

Jean-François Bach and Lucienne Chatenoud

For additional articles in this collection, see http://perspectivesinmedicine.cshlp.org/cgi/collection/ 